\title{
Potency of Combination of Fucoidan Microsphere and MiRNA-200b as Therapy in Chemoresistant Breast Cancer
}

Potensi Kombinasi Mikrosfer Fukoidan dan MiRNA-200b sebagai Terapi pada Kanker Payudara Kemoresisten

\author{
Sinta Wiranata*, Made VW Yani*, Agung BS Satyarsa*, I Ketut R Ardiana*, Putu \\ AT Adiputra** \\ *Faculty of Medicine Udayana University, Denpasar, Bali, Indonesia \\ **Division of Surgery Oncology Department of Surgery Faculty of Medicine Udayana \\ University - Sanglah General Hospital, Denpasar, Bali, Indonesia \\ E-mail: sintawiranata@student.unud.ac.id
}

Received: November 12, 2018

Accepted: February 25, 2020

\begin{abstract}
Breast cancer still become a major health problem in Indonesia and worldwide until today. Based on WHO 2012, breast cancer incidence is reported as 1.67 million cases with $90 \%$ of mortality rate in the metastasis stage. Chemoresistant is one cause of this increased mortality and morbidity. Nowadays, there are many treatment choices for cancer, but $90 \%$ incident of chemoresistant breast cancer occur even with prior chemotherapy. This review aimed to describe the potential of microsphere combinations fucoidan and miRNA-200b as a treatment for chemoresistant in breast cancer. Literature review were derived from scientific journals using www.pubmed.com and scholar.google.com database with "chemoresistant breast cancer, Fucoidan, microRNA-200b" as keyword. Fucoidan can induce apoptosis through the extrinsic pathway involving apoptotic receptor, or intrinsic pathway involving changes in mitochondrial membrane potential (MMP) to release cytochrome $C$ and activating the apoptotic signal. Meanwhile, miRNA-200b expression, will decrease Spl expression and decrease histone-3 acetylation level in a miRNA-200b promoter, resulting in decreased cancer cell migration and invasion. However, no studies have evaluated this combination clinically. So, further studies are needed to confirm the potential of microsphere combination fucoidan and miRNA-200b in chemoresistant breast cancer.
\end{abstract}

Keywords: chemoresistant breast cancer; Fucoidan; miRNA-200b.

\begin{abstract}
Abstrak
Sampai saat ini, kanker payudara masih menjadi masalah utama kesehatan di Indonesia maupun di dunia. Menurut WHO tahun 2012, kejadian kanker payudara dilaporkan sebanyak 1,67 juta kasus dengan angka kematian $90 \%$ pada stadium lanjut. Salah satu penyebab peningkatan mortalitas dan morbiditas yaitu kemoresistensi. Saat ini telah banyak terapi untuk kanker namun terjadi $90 \%$ kejadian kanker payudara kemoresisten walaupun sudah dikemoterapi sebelumnya. Tujuan tinjauan ini yaitu untuk menggambarkan potensi kombinasi mikrosfer fukoidan dan miRNA-200b sebagai pengobatan kanker payudara kemoresisten. Metode yang digunakan yaitu studi pustaka dengan penelusuran database www.pubmed.com dan scholar.google.com menggunakan kata kunci "chemoresistant breast cancer, Fucoidan, microRNA-200b”. Fukoidan dapat menginduksi apoptosis melalui jalur ekstrinsik yang melibatkan reseptor apoptosis, atau jalur intrinsik yang melibatkan perubahan mitochondrial membrane potential (MMP) untuk
\end{abstract}




\section{Review Article}

melepaskan sitokrom C dan aktivasi sinyal apoptosis. Ekspresi miRNA-200b menurunkan ekspresi Sp1 dan menurunkan tingkat asetilasi histone-3 pada promoter miRNA-200b sehingga menurunkan migrasi serta invasi sel kanker. Hingga saat ini belum terdapat penelitian yang mengevaluasi kombinasi ini secara klinis. Oleh sebab itu, perlu dilakukan penelitian lebih lanjut untuk mengkonfirmasi potensi kombinasi mikrosfer fukoidan dan miRNA-200b pada kanker payudara kemoresisten.

Kata kunci: kanker payudara kemoresisten; Fukoidan; miRNA-200b

\section{Pendahuluan}

Sampai saat ini kanker payudara masih menjadi masalah kesehatan utama di dunia termasuk di Indonesia. Berdasarkan data statistik WHO tahun 2017, sekitar 2,1 juta orang terkena kanker payudara dan 90\% terdiagnosis pada tahap metastasis sehingga meningkatkan mortalitas. ${ }^{1}$ Berdasarkan data dari IARC tahun 2012, insiden kanker payudara sebesar 40 per 100.000 perempuan. $^{2}$

Breast cancer stem cell (BCSC) memiliki kemampuan untuk tumbuh kembali, membentuk tumor baru dan menyebabkan terjadinya kemoresistensi. Kemoresisten BCSC dapat dibagi menjadi dua kelompok utama yaitu resistensi intrinsik karena perubahan genetik dan resistensi ekstrinsik karena pengaruh micro-environtment. ${ }^{3}$ Resistensi intrinsik termasuk ekspresi yang berlebihan dari ATP yang mengikat ABC transporter, mekanisme perbaikan DNA, perubahan siklus sel, ekspresi berlebihan ALDH1 dan resistensi terhadap apoptosis. Pengaruh ekstrinsik mencakup hipoksia atau EMT yang mengarah pada terjadinya kemoresistensi. ${ }^{3}$

Berdasarkan paparan data di atas, maka diperlukan suatu upaya dalam penatalaksanaan kanker payudara kemoresisten. Salah satu upaya yang telah dilakukan yaitu dengan pembedahan dan kombinasi kemoterapi untuk menginduksi apoptosis pada sel kanker kemoresisten. Pembedahan dan kombinasi kemoterapi menunjukkan efek yang tidak signifikan dalam menginduksi apoptosis sel kanker dan 90\% kanker dapat muncul kembali meski telah mendapatkan kemoterapi sebelumnya. ${ }^{1,2,4}$ Efek samping dari kombinasi kemoterapi memberikan dampak negatif bagi pasien, ${ }^{4,5}$ sehingga diperlukan modalitas yang dapat meminimalkan efek samping serta meningkatkan kualitas terapi secara holistik sebagai upaya penatalaksanaan kanker payudara kemoresisten.

Penatalaksanaan kanker payudara kemoresisten kini beralih ke fitofarmaka. ${ }^{6}$ Menurut hasil penelitian Xue et al tahun 2012, fukoidan dari ekstrak rumput laut coklat memiliki potensi antiproliferasi dan proapoptosis sel MCF-7 dan sel MDA-MB-231 pada kanker payudara dengan memengaruhi regulasi pada jalur pI3K/Akt/mTOR, Bcl-2, Bax, CDK, kaspase, THP-1, JNK serta 


\section{Review Article}

MAPK ${ }^{7-10}$ Selain itu, terapi gen juga dilirik sebagai terapi kanker seperti miRNA. miRNA adalah short RNA, salah satunya yaitu miRNA-200b yang memiliki fungsi untuk mengatur proliferasi, apoptosis, angiogenesis, metastasis, invasi serta kemoresistensi dari sel kanker. ${ }^{4,11}$ miRNA-200b memiliki potensi untuk meningkatkan sensitivitas sel target dengan kemoterapi. ${ }^{12-14}$ Selain itu, ekspresi dari miRNA-200b dapat bersifat antimetastasis spesifik pada protein FOG2 dari sel kanker payudara kemoresisten. ${ }^{15}$ Demi meningkatkan efektivitas pengantaran obat, maka dapat digunakan partikel berdiameter $50 \mathrm{~nm}-20 \mu \mathrm{m}$ dengan substansi inti yang disebut dengan mikrosfer. Melihat potensi terapi dari mikrosfer fukoidan dan miRNA200b pada penatalaksanaan kanker payudara kemoresisten, maka modalitas ini dapat menjadi terobosan baru terapi pada penatalaksanaan kanker payudara kemoresisten. Dengan demikian, perlu dibahas lebih lanjut mengenai modalitas spesifik ini sehingga memberikan prospek yang cerah dalam penatalaksanaan kanker payudara kemoresisten.

\section{Metode}

Penulisan tinjauan pustaka ini menggunakan metode studi pustaka. Sumber literatur terdiri dari jurnal-jurnal yang relevan dari mesin pencari seperti https://www.ncbi.nlm.nih.gov/pubmed/, www.proquest.com, dan https://scholar.google.com/. dengan menggunakan kata kunci: "Chemoresistant breast cancer, Fucoidan, microRNA-200b". Kriteria inklusi adalah semua artikel mengenai kanker payudara, dan referensi tidak melebihi 10 tahun terakhir, kecuali jika tidak ada penelitian terbaru yang menentang isi dari referensi tersebut. Dari 85 jurnal yang ditinjau, terdapat 50 jurnal yang sesuai untuk dijadikan referensi pada tulisan ini.

\section{Diskusi}

\section{Penurunan Regulasi Mirna-200b dalam Patogenesis Kanker Payudara Kemoresisten}

Breast cancer stem cell (BCSC) kemoresisten dapat dibagi menjadi dua kelompok utama yaitu resistensi kemoterapi intrinsik dan ekstrinsik. ${ }^{13}$ Resistensi intrinsik meliputi overexpression dari ATP, reaksi berlebih dari ALDH1 dan resistensi terhadap apoptosis. ${ }^{13,14}$ Resistensi intrinsik ditandai dengan potensi sel untuk bertahan dalam pengobatan kemoterapi yang disebabkan oleh pengangkutan $\mathrm{ABC}$ pada $\mathrm{BCSC} .{ }^{12}$ Protein pengangkut $\mathrm{ABC}$ menggunakan energi dari pengikatan ATP dan reaksi hidrolisis untuk mengangkut substrat seperti obat antikanker. ${ }^{14}$

Transpor $\mathrm{ABC}$ dengan cepat menimbulkan mekanisme pompa efllux yang menyebabkan transpor ABC melindungi BCSC terhadap kerusakan sel akibat obat kemoterapi. ${ }^{14-16}$ Resistensi 


\section{Review Article}

intrinsik juga disebabkan oleh reaksi berlebih terhadap ALDH1 sebagai biomarker untuk identifikasi BCSC serta berperan dalam metabolisme agen kemoterapi ${ }^{14-17}$ Resistensi ekstrinsik meliputi pengaruh lingkungan mikro seperti hipoksia dan EMT. ${ }^{14}$ Epithelial-mesenchymal transitions memiliki beberapa regulasi jalur persinyalan seperti twist, snail, dan Wnt yang dapat meningkatkan ketahanan sel kanker dalam paparan kemoterapi dan ketahanan terhadap paclitaxel. $18-20$

Penurunan regulasi miR-200b dapat menyebabkan kanker payudara kemoresisten melalui target $\mathrm{Sp} 1 .^{21,22} \mathrm{Sp} 1$ mampu menarik HDAC1 ke promotor fosfatase selanjutnya menghambat ekpresi PTEN sehingga meningkatkan asetilasi histon-3 pada promotor miR-200b dan meningkatkan migrasi serta invasi. ${ }^{23,24}$ Ketika tempat pengikatan Sp1 bermutasi, efek HDAC1/4 pada promoter miR-200b melemah dan menyebabkan sel kanker tahan terhadap kemoterapi. ${ }^{22}$ Sp1 juga berperan dalam mendukung EMT yang diinduksi TGF- $\beta$ melalui aktivitas snail dan bertindak sebagai kofaktor dengan kompleks smader TGF- $\beta .^{25}$

Hilangnya ekspresi miR-200b juga dapat disebabkan oleh peningkatan ekspresi pin1 yang menurunkan apoptosis melalui AKT integrin mediated cell death. Akibat dari hilangnya pengaturan apoptosis ini, sel dapat bermetastasis dan tidak mengalami apoptosis ketika terlepas dari matriks ekstraseluler, dan menghambat pembentukan EMT. ${ }^{26}$ miRNA-200b dapat mengatur sinyal VEGF dengan menargetkan VEGF dan reseptornya. Overexpression dari miRNA-200b mengurangi fosforilasi ERG1/2 yang diinduksi oleh penurunan VEGF. Melalui penurunan regulasi, miRNA-200b dan ERK1/2 difosforilasi melalui pensinyalan VEGF bersamaan dengan efek Pin1 pada pERK sehingga menghasilkan sel kanker yang memperoleh kemampuan untuk melawan apoptosis. ${ }^{26} \mathrm{MiRNA}-200 \mathrm{~b}$ dapat mengatur proliferasi dalam dua cara yaitu melalui penargetan RND3 dan FOG2, yang dapat mengatur proliferasi sel melalui jalur PI3K/AKT. ${ }^{27,28}$

\section{Peran Fukoidan Dalam Induksi Apoptosis, Cell Cycle Arrest, Metastasis dan Antiproliferasi Kanker Payudara}

Ekspresi miRNA-200b dalam sel kanker payudara kemoresisten mampu menurunkan ekspresi Sp1. Akibatnya, Sp1 tidak mampu menarik HDAC1 ke promotor fosfatase sehingga ekpresi PTEN meningkat. Meningkatnya PTEN tersebut dapat menurunkan tingkat asetilasi histon-3 pada promotor miRNA-200b sehingga menurunkan migrasi sel kanker serta invasi. Selain itu, penurunan ekspresi Sp1 juga berperan dalam penurunan ekspresi EMT yang akan berubah menjadi MET sebagai anti metastasis, sehingga dapat menjadi sel target dari fukoidan dalam terapi kanker payudara kemoresisten. ${ }^{22}$ 


\section{Review Article}

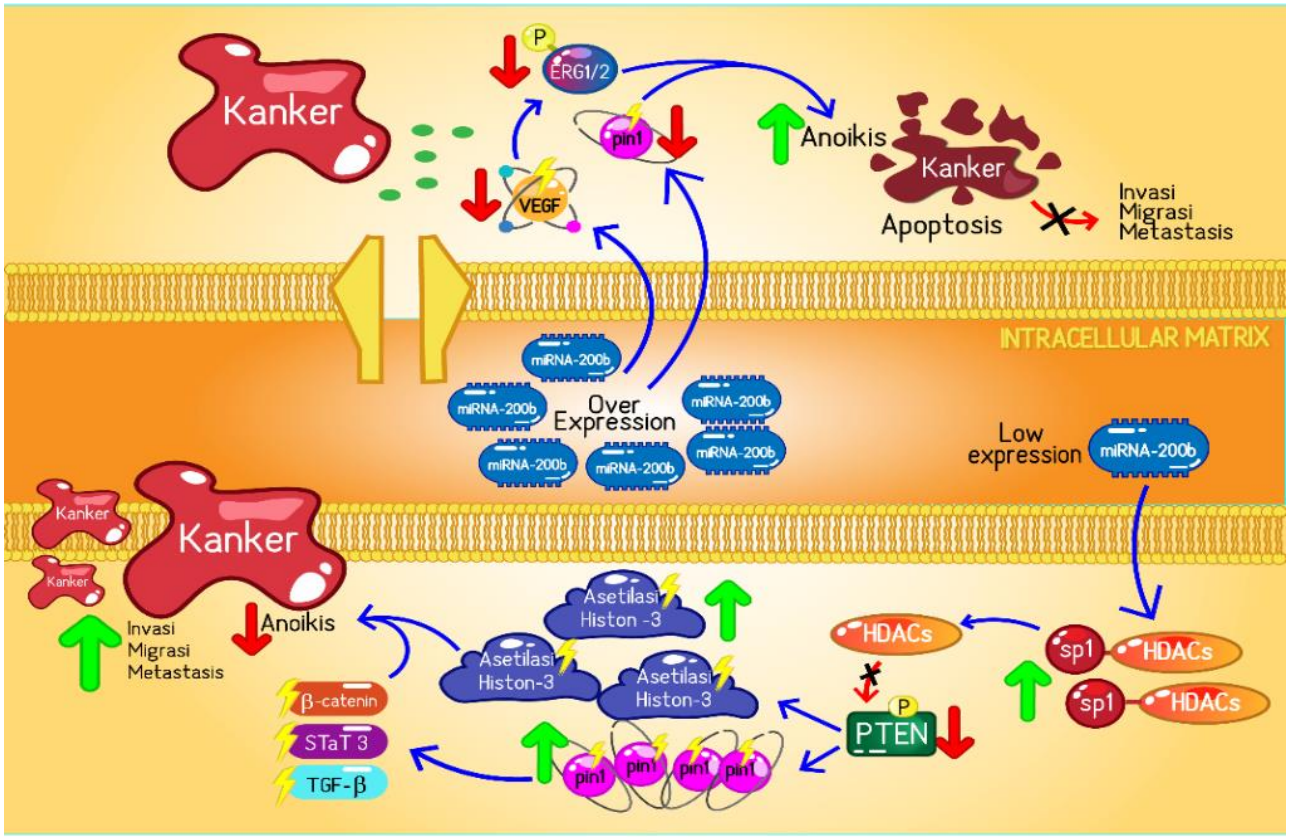

\section{Gambar 1 Skema Peranan miRNA-200b dalam Patogenesis Kanker Payudara}

\section{Kemoresisten $^{14,15,25-28,17-24}$}

miRNA-200b memiliki kemampuan dalam menekan proliferasi dan menginduksi apoptosis pada sel kanker payudara manusia secara in vitro. Ekspresi miRNA-200b yang tinggi secara signifikan menekan proliferasi sel MDA-MB-231 sebesar 11,69 $\pm 2,17 \%$. Inhibitor miRNA-200b meningkatkan pertumbuhan sel MCF-7 masing-masing sebesar 21,93 $\pm 2,07 \%$. Ekspresi miRNA-200b meningkatkan apoptosis dari 4,07\% \pm 0,95\% menjadi 16,29\% $\pm 1,64 \%$ dibandingkan dengan $\mathrm{NC}$, dan juga meningkatkan persentase sel dalam fase G2/M dari 11,69\% $\pm 1,33 \%$ menjadi $24,95 \% \pm 2,31 \%$, serta penurunan pada fase $\mathrm{S}$ dari $39,67 \% \pm 3,50 \%$ menjadi $27,83 \% \pm 1,10 \% .^{22}$

Berdasarkan hasil penelitian sebelumnya, fukoidan memiliki potensi sebagai antikanker, antiangiogenesis, antimetastasis, antioksidan, imunomodulator serta pengatur kadar lipid dalam darah. ${ }^{8,9,29-31}$ Pada penelitian oleh Zhang et al tahun 2013, bahwa fukoidan memiliki potensi sebagai agen antiproliferasi sebesar 80-85,3\% sel kanker payudara yaitu sel MDA-MB-231 pada mencit. $^{32}$ 
Tabel 1 Penelitian dan Uji Klinis Efek MiRNA-200b dan Fukoidan pada Kanker Payudara. ${ }^{22,31-33,40}$

\begin{tabular}{lll}
\hline Judul Penelitian & Peneliti & Hasil \\
\hline MiR-200b expression in breast & Yao Y et al, & Ekspresi miRNA-200b dalam sel kanker payudara \\
cancer: a prognostic marker and & 2015. & kemoresisten mampu menurunkan ekspresi Sp1, \\
act on cell proliferation and & sehingga Sp1 tidak mampu menarik HDAC1 ke \\
apoptosis by targeting Sp1 & promotor fosfatase dan ekpresi PTEN akan \\
& meningkat Meningkatnya PTEN akan \\
& menurunkan tingkat asetilasi histon-3 pada \\
& promotor miRNA-200b sehingga menurunkan \\
& migrasi serta invasi sel kanker. Inhibitor miRNA- \\
& 200b meningkatkan pertumbuhan sel MCF-7 \\
& masing-masing sebesar 21,93 $2,07 \%$. Sementara \\
& itu, ekspresi tinggi dari miRNA-200b mampu \\
& menekan proliferasi sel MDA-MB-231 secara \\
& signifikan.
\end{tabular}

Induction of apoptosis by low molecularweight fucoidan through calcium and caspase dependent mitochondrial pathways in MDA-MB-231 breast cancer cells.
Zhang $\mathrm{Z}$ et Fukoidan dengan berat molekul rendah atau The al, $2013 \quad$ low molecular weight Fukoidan (LMWF) pada sel kanker payudara MDA-MB-231 dikaitkan dengan aktivasi caspase dan disfungsi mitokondria, termasuk disipasi potensial membran mitokondria, perubahan homeostasis $\mathrm{Ca}^{2+}$, pelepasan sitokrom c dan penurunan ekspresi protein antiapoptotik Bcl2. Fukoidan berpotensi sebagai agen antiproliferasi sebesar $80-85,3 \%$ pada sel kanker payudara MDAMB-231 yang diuji secara in vivo.

Banafa A.M Fukoidan dapat menginduksi migrasi sitokrom C et al, 2013. dari mitokondria ke sitosol dan mengatur protein apoptosis pada sel MCF-7. Hasil tes flow cytometry menunjukkan terjadinya apoptosis pada sel kanker payudara sebesar $75 \%$ selama 48 jam.

Yamasaki Y Fukoidan sebesar $1000 \mu \mathrm{g} / \mathrm{mL}$ diberikan pada sel et al, 2009. line MCF-7 selama 24, 48, 72, dan 96 jam. Hasilnya fukoidan mampu menurunkan regulasi dari Bcl-2, Bid, CDKs, serta meningkatkan regulasi Bax, kaspase 8 , sitokrom $\mathrm{C}, \beta$-actin

Didukung pula oleh penelitian Atashrazm tahun 2015, bahwa fukoidan menyebabkan penurunan signifikan regulasi cyclin D1, cyclin D2 and CDK4 pada siklus sel kanker payudara. ${ }^{29}$ Selain itu, terjadi peningkatan pada sub-G0/G1 sehingga menyebabkan penahanan fase G0/G1 yang menyebabkan penekanan aktivitas CDK diikuti penghambatan CDK2 dan CDK4 pada proses proliferasi sel kanker. ${ }^{30,31}$ Fukoidan sebagai agen antiproliferasi juga menekan aktivitas MMP-2 dengan menurunkan regulasi PI3K-Akt-mTOR, Wnt serta MAPK dalam menghentikan proliferasi dan metastasis. ${ }^{33-35}$ Dengan demikian, fukoidan dapat menghambat proliferasi sel 


\section{Review Article}

kanker payudara baik secara in vivo maupun in vitro. ${ }^{8,9}$ Hasil penelitian dan uji klinis efek mirna200b dan fukoidan pada kanker payudara dapat dilihat pada tabel 1.

Fukoidan dapat mempengaruhi regulasi Bcl-2 dan Bad dengan menurunkan ekspresi protein Bcl-2 dan memodulasi ekspresi protein Bax dalam menginduksi apoptosis sel MCF-7. ${ }^{9}$ Fukoidan juga menginduksi apoptosis dengan meningkatkan regulasi THP-1, sehingga terjadi peningkatan IFN- $\gamma$, IL-12, Bax dan TNF- $\alpha$ serta penurunan regulasi Bcl-2 protein, Bid, dan Bad. ${ }^{34,36,37}$ Fukoidan juga menekan EGF-R yang menekan migrasi dan invasi sel kanker, ${ }^{35,38}$ sehingga terjadi penurunan regulasi jalur pI3K-Akt-mTOR yang mengakibatkan penurunan ekspresi MMP-2 dan apoptosis pada sel kanker payudara. ${ }^{32,35}$ Selain itu, fukoidan juga menginduksi apoptosis melalui aktivasi kaspase, regulasi JNK, ERK dan p38 signaling, STAT, Bcl-2 protein dan Akt, menekan VEGF dan penghambatan EGFR. ${ }^{37-39}$ Fukoidan memiliki bioaktivitas dalam menghambat VEGF dan apoptosis sehingga sel kanker tidak dapat invasi dan kekurangan nutrisi. ${ }^{40,41}$

\section{Simpulan}

Mikrosfer kombinasi fukoidan dan miRNA-200b memiliki potensi yang unggul, yaitu sebagai zat aktif terapi kanker serta pembentukan mikrosfer polimer sebagai mikropartikel. Mikrosfer kombinasi fukoidan dan miRNA-200b juga bekerja pada multi-target untuk menginduksi apoptosis maksimal pada sel kanker payudara kemoresisten dan tidak meninggalkan residu asing berbahaya di dalam tubuh, karena dapat didegradasi oleh makrofag. Keterbatasan dari mikrosfer kombinasi fukoidan dan miRNA-200b, yaitu bioavailabilitas berkurang jika dikonsumsi secara oral, belum terdapat penelitian lanjutan yang membahas hubungan dari mikrosfer kombinasi fukoidan dan miRNA-200b.

\section{Daftar Pustaka}

1. World Health Organisation [database on the Internet] Cancer Control: Knowledge into Action - WHO Guide for Effective Programmes. [cited 2019 Jan 21]. Available from :https://www.who.int/cancer/modules/ en/

2. International Agency for Research on Cancer [database on the Internet]. Estimated Cancer Incidence, Mortality and Prevalence Worldwide in 2012.[cited 2019 Jan 21]. Available from : http://gco.iarc.fr

3. Rebucci M, Michiels C. Molecular aspects of cancer cell resistance to chemotherapy. Biochem Pharmacol. 2013; 85(9): 1219-26.

4. Pinto R, Summa S, Pilato B, Tommasi S. DNA methylation and miRNAs regulation in hereditary breast cancer: epigenetic changes, players in transcriptional and post- transcriptional regulation in hereditary breast cancer. Curr Mol Med. 2014; 14(1): 45-57.

5. Breast Cancer Organization [homepages on the Internet]. What are the side effects of chemotherapy? [updated 2018 Oct 16; cited 2019 Feb 11] Available from: https://www.breastcancer.org/treatment

6. Shirahata S, Zhang Z, Yoshida T, Eto H, Teruya K. Fukoidan extract enhances the anti-cancer activity of chemotherapeutic agents in breast cancer cells. BMC Proc. 2013;7(6):81-98.

7. Zhang J, Ruby JE, Conde L, Grizzle WE, Cui X, Skibola CF. A fucus vesiculosus extract inhibits estrogen receptor 


\section{Review Article}

activation and induces cell death in female cancer cell lines. BMC Complement Altern Med. 2016;16: 151.

8. Senthilkumar K, Manivasagan P, Venkatesan J, Kim SK. Brown seaweeds fukoidan: biological activity and apoptosis, growth signaling mechanism in cancer. Int J Biol Macromol. 2013; 60: 366-74.

9. Xue M, Ge Y, Zhang J, Wang Q, Hou L, Liu Y, et al. Anticancer properties and mechanisms of fukoidan on mouse breast cancer in vitro and in vivo. PLoS ONE. 2012;7(8): 3-11.

10. Pinheiro AC, Bourbon AI, Cerqueira MA, Maricato É, Nunes C, Coimbra MA, et al. Chitosan / fukoidan multilayer nanocapsules as a vehicle for controlled release of bioactive compounds. Carbohydr Polym. 2015; 115: 1-9.

11. Gantier MP, McCoy CE, Rusinova I, Saulep D, Wang D, Xu D, et al. Analysis of microRNA turnover in mammalian cells following Dicer1 ablation. Nucleic Acids Res. 2011;39(13): 5692-703.

12. Li X, Lewis MT, Huang J, Gutierrez C, Osborne CK, Wu MF, et al. Intrinsic resistance of tumorigenic breast cancer cells to chemotherapy. J Natl Cancer Inst. 2008;100(9): 672-9.

13. Rebucci M, Michiels C. Molecular aspects of cancer cell resistance to chemotherapy. Biochem Pharmacol.2013;85(9): 1219-26.

14. Verwey M, Joubert AM, Visagie MH, Theron AE. Chemoresistance in breast cancer stem cells. Biomedical Research. 2016; 27(1): 16-23.

15. Economopoulou P, Kaklamani VG, Siziopikou K. The role of cancer stem cells in breast cancer initiation and progression: potential cancer stem cell-directed therapies. Oncologist. 2012; 17(11): 1394-401.

16. Chuthapisith S, Eremin J, El-Sheemey M, Eremin O. Breast cancer chemoresistance: Emerging importance of cancer stem cells. Surg Oncol. 2010;19(1): 27-32.

17. Croker AK, Allan AL. Inhibition of aldehyde dehydrogenase (ALDH) activity reduces chemotherapy and radiation resistance of stem-like ALDHhiCD44+ human breast cancer cells. Breast Cancer Res Treat. 2012; 133(1): 75-87.

18. Wang Y, Zhou BP. Epithelial-mesenchymal transition in breast cancer progression and metastasis. Chin J Cancer. 2011; 30(9): 603-11.

19. Wu Y, Zhou BP. New insight of ephitelial-mesenchymal transition in cancer metastasis. Acta Biochem Biophys Sin. 2008; 40(7): 643-50.

20. Hu T, Li C. Convergence between Wnt-B-catenin and EGFR signaling in cancer. Mol Cancer. 2010; 9(1):1-7.

21. Wee EJ, Peters K, Nair SS, Hulf T, Stein S, Wagner S, et al. Mapping the regulatory sequences controlling 93 breast cancer-associated miRNA genes leads to the identification of two functional promoters of the Hsa-mir-200b cluster, methylation of which is associated with metastasis or hormone receptor status in adva. Oncogene. 2012; 31(38): 4182-95.

22. Yao Y, Hu J, Shen Z, Yao R, Liu S, Li Y, et al. MiR-200b expression in breast cancer: a prognostic marker and act on cell proliferation and apoptosis by targeting Sp1. J Cell Mol Med. 2015;19(4): 760-9.

23. Chen DQ, Pan BZ, Huang JY, Zhang K, Cui SY, De W, et al. HDAC 1/4-mediated silencing of microRNA-200b promotes chemoresistance in human lung adenocarcinoma cells. Oncotarget. 2014; 5(10): 3333-49.

24. Yuan JH, Yang F, Chen BF, Lu Z, Huo XS, Zhou WP, et al. The histone deacetylase 4/SP1/microrna-200a regulatory network contributes to aberrant histone acetylation in hepatocellular carcinoma. Hepatology. 2011;54(6): 2025-35

25. Kolesnikoff N, Attema JL, Roslan S, Bert AG, Schwarz QP, Gregory PA, et al. Specificity protein 1 (Sp1) maintains basal epithelial expression of the mir-200 family: Implications for epithelial-mesenchymal transition. J Biol Chem. 2014; 289(16): 11194-205.

26. Zhang X, Zhang B, Gao J, Wang X, Liu Z. Regulation of the miRNA-200b by transcriptional regulators PEA3 and ELK-1 affects expression of Pin1 to control apoptosis. J Biol Chem. 2013; 288(45): 32742-52.

27. Xia W, Li J, Chen L, Huang B, Li S, Yang G, et al. MicroRNA-200b regulates cyclin D1 expression and promotes S-phase entry by targeting RND3 in HeLa cells. Mol Cell Biochem. 2010; 344(1-2): 261-6.

28. Cortez MA, Bueso-Ramos C, Ferdin J, Lopez-Berestein G, Sood AK, Calin GA, MicroRNAs in body fluids-the mix of hormones and biomarkers. Nat Rev Clin Oncol. 2011;8(8): 467-77.

29. Cumashi A, Ushakova NA, Preobrazhenskaya ME, D'Incecco A, Piccoli A, Totani L, et al. A comparative study of the anti-inflammatory, anticoagulant, antiangiogenic, and antiadhesive activities of nine different fucoidans from brown seaweeds. Glycobiology. 2007; 17(5): 541-52.

30. Atashrazm F, Lowenthal RM, Woods GM, Holloway AF, Dickinson JL. Fukoidan and Cancer: A Multifunctional Molecule with Anti-Tumor Potential. Mar Drugs. 2015; 13(4): 2327-46

31. Banafa AM, Roshan S, Liu YY, Chen HJ, Chen MJ, Yang GX, et al. Fukoidan induces G1 phase arrest and apoptosis through caspases-dependent pathway and ROS induction in human breast cancer MCF-7 cells. J Huazhong Univ Sci Technol Med Sci. 2013;33(5): 717-24.

32. Zhang Z, Teruya K, Eto H, Shirahata S. Induction of Apoptosis by Low-Molecular-Weight Fukoidan through Calcium- and Caspase-Dependent Mitochondrial Pathways in MDA-MB-231 Breast Cancer Cells. Biosci Biotechnol Biochem. 2013; 77(2): 235-42.

33. Yamasaki-Miyamoto Y, Yamasaki M, Tachibana H, Yamada K. Fucoidan induces apoptosis through activation of caspase-8 on human breast cancer MCF-7 cells. J Agric Food Chem. 2009; 57(18): 8677-82.

34. Kwak JY. Fucoidan as a marine anticancer agent in preclinical development. Mar Drugs. 2014;12(2): 851-70.

35. Huang TH, Chiu YH, Chan YL, Chiu YH, Wang H, Huang KC, et al. Prophylactic administration of Fucoidan 


\section{Review Article}

represses cancer metastasis by inhibiting vascular endothelial growth factor (VEGF) and matrix metalloproteinases (MMPs) in Lewis tumor-bearing mice. Mar Drugs. 2015; 13(4): 1882-900.

36. Kalimuthu S, Kim SK. Fucoidan, a sulfated polysaccharides from Brown Algae as therapeutic target for cancer. Handbook of Anticancer Drugs from Marine Origin. 2015;1(1):145-64.

37. Fitton JH. Therapies from Fukoidan; multifunctional marine polymers. Mar Drugs;9(1): 1731-60.

38. Moussavou G, Kwak DH, Obiang-Obnou BW, Maranguy CA, Dinzouna-Boutamba SD, Lee DH, et al. Anticancer effects of different seaweeds on human colon and breast cancers. Mar Drug; 12(9): 4898-911.

39. Tryndyak VP, Beland FA, Pogribny IP. E-cadherin transcriptional down-regulation by epigenetic and microRNA200 family alterations is related to mesenchymal and drug-resistant phenotypes in human breast cancer cells. Int $\mathbf{J}$ Cancer; 126(11): 2575-83.

40. Zhang Z, Teruya K, Eto H, Shirahata S. Fukoidan Extract Induces Apoptosis in MCF-7 Cells via a Mechanism Involving the ROS-Dependent JNK Activation and Mitochondria-Mediated Pathways. PLoS One;6(11):1-14.

41. Chen S, Zhao Y, Zhang Y, Zhang D. Fucoidan induces cancer cell apoptosis by modulating the endoplasmic reticulum stress cascades. PLoS One; 9(9): 1-10.

\section{Daftar Singkatan}

ALDH1 : aldehyde dehydrogenase 1

ATP: adenosin trifosfat

ABC: ATP-binding cassette

BCSC: Breast cancer stem cell

CDKs: Cyclin-dependent kinases

DNA: deoxyribonucleic acid

EGFR: Epidermal growth factor receptor

EMT: epithelial-mesenchymal transitions

ERG: ETS related gene

ERK: Extracellular signal-regulated kinase

HDAC1: Histone deacetylase 1

IARC: International Agency for Research on Cancer

IFN: Interferon
JNK: Jun N-terminal kinase

MAPK: mitogen-activated protein kinase miRNA: microRNA, Mtor: mammalian target of rapamycin

MMP: Matrix Metalloproteinase

PI3Ks/AKT: Phosphoinositide 3-kinases

PTEN: phosphatase and tensin homologue

STAT: signal transducer and activator of transcription

TGF: Transforming Growth Factor

TNF: Tumor Necrosis Factor

VEGF: Vascular endothelial growth factor

WHO: World Health Organization 